\title{
A KÍNAI-PAKISZTÁNI KAPCSOLATOK BIZTONSÁGPOLITIKAI ASPEKTUSAI: SZEMÉLYEK ELLENI TÁMADÁSOK
}

\section{SECURITY ASPECTS OF CHINA-PAKISTAN RELATIONS: ATTACTS AGAINST PEOPLE}

\author{
Günsberger Dóra \\ tudományos segédmunkatárs, Pázmány Péter Katolikus Egyetem Bölcsészettudományi Kar Modern Kelet-Ázsia Kutatócsoport \\ gunsberger.dora@ppke.hu
}

\begin{abstract}
ÖSSZEFOGLALÁS
A pakisztáni témájú tudományos munkák nagy része az ország instabil biztonsági helyzetével, illetve ennek Pakisztán külkapcsolataira gyakorolt hatásaival foglalkozik. A kétoldalú kapcsolatok szempontjából a külföldiek elleni támadások jelentik az egyik legfőbb kihívást: míg korábban a külföldi személyek elleni támadások túlnyomó többsége európai és észak-amerikai országok állampolgárait érte, új tendencia a kínai állampolgárok elleni támadások számának növekedése. Mely csoportok állnak a kínai állampolgárok ellen elkövetett támadások mögött, és milyen motivációk húzódnak meg a háttérben? Jelen tanulmány célja, hogy a Pakisztánban 2007 és 2017 között kínai állampolgárok ellen elkövetett merényletek elemzése alapján rámutasson a kifejezetten kínai személyekre veszélyt jelentő csoportok tevékenységére és ezek változó tendenciáira. Az írás első része a dzsihádista csoportok által elkövetett támadásokat elemzi. Ezt követi az ujgur szeparatizmus pakisztáni jelenlétének és esetleges ideológiai befolyásának tárgyalása. A tanulmány a növekvő kínai gazdasági jelenlét kontextusában a beludzs és szindhi szeparatista csoportok által elkövetett támadásoknak és azok motivációinak elemzésével fejeződik be.
\end{abstract}

\section{ABSTRACT}

Scholarly works on contemporary Pakistan have long been dominated by a security-focused approach, including the implications of the generally volatile security situation on Pakistan's foreign relations. From the perspective of bilateral relations, attacks against foreigners is one of the most crucial issues. While the primary target of the groups behind these offensives evidently remain citizens of European and North American countries, the increasing number of attacks against Chinese citizens in Pakistan over the last decade highlight a changing tendency. Which groups pose a threat to Chinese citizens living in Pakistan and what motivations lie behind the attacks? The primary aim of this study is to highlight the patterns and changing tendencies of attacks against Chinese citizens in Pakistan between 2010 and 2017. In the first part of the paper 
I look at the threat posed by jihadist groups, followed by highlighting the ramifications of Uighur separatist groups' physical presence and ideology in Pakistan. Lastly, I analyse a new form of threat posed by Baluch and Sindhi nationalist groups in juxtaposition with growing Chinese economic presence in Pakistan.

Kulcsszavak: Pakisztán, Kína, biztonság, Kína-Pakisztán Gazdasági Folyosó, dzsihadizmus, szeparatizmus, terrorizmus, iszlám

Keywords: Pakistan, China, security, China-Pakistan Economic Corridor, jihadism, separatism, terrorism, Islam

\section{BEVEZETÉS}

A kínai-pakisztáni kapcsolatok fenntartása, fejlesztése és ápolása egyike azon kevés pontoknak, melyeket széles körü politikai konszenzus övez Pakisztánban. Ez jól mutatja a bilaterális viszony fontosságát, ám az ország instabil biztonsági helyzete több szempontból is hatással van a gondosan ápolt kínai-pakisztáni kapcsolatokra. A biztonsági fenyegetések közül kiemelt fontosságú a személyek biztonsága és az ezt veszélyeztető faktorok, főként a pakisztáni szélsőséges csoportok eröszakos tevékenysége miatt. Bár az ezen csoportok által elkövetett támadások elsődleges célpontjai amerikai és európai személyek, az utóbbi évtizedek során egyre gyakoribbá váltak a kínai állampolgárok ellen elkövetett merényletek Pakisztánban. Mi ennek a változásnak az oka, mely csoportok állnak ezek mögött, és mi motiválja az elkövetőket? Jelen tanulmány célja, hogy a kétségkívül számtalan biztonsági fenyegetés közül - így a teljesség nyilvánvaló igénye nélkül - ezt a problémakört kiemelje és elemezze.

Az elemzés alapja a Pakisztán területén kínai állampolgárok ellen az elmúlt tíz év során elkövetett, a pakisztáni sajtóban megjelent és hivatalos források által megerősített támadások összefoglaló listája, mely tartalmazza a merényletek idejét, helyét, módját és az elkövető csoport nevét.

A fenti adatok alapján négy motivációt különíthetünk el: haszonszerzés (emberrablások); ideológiai megfontolás; gazdasági elnyomás, kizsákmányolás és kulturális imperializmus elleni tiltakozás; valamint ismeretlen indokból elkövetett támadások. Az ideológiai okból és haszonszerzés céljából elkövetett támadások elsősorban dzsihádista csoportokhoz köthetők, míg az utóbbi, egzisztenciális félelem által motivált merényletek mögött szubnacionalista-szeparatista csoportok állnak. A következőkben a tanulmány a fent vázolt két támadási motivációt és az ezekhez kapcsolódó csoportokat mutatja be, illetve a tendenciák változását elemzi. 
Pakisztán területén kínai állampolgárok ellen elkövetett támadások, 2007-2017

\begin{tabular}{|c|c|c|c|c|}
\hline Dátum & Helyszín & $\begin{array}{l}\text { Támadás } \\
\text { módja }\end{array}$ & $\begin{array}{l}\text { Sérültek/ } \\
\text { halottak }\end{array}$ & Elkövető \\
\hline 2007. június 22 . & $\begin{array}{l}\text { Iszlámábád } \\
\text { (Pandzsáb) }\end{array}$ & emberrablás & 9 & $\begin{array}{l}\text { Lál } \\
\text { Maszdzsid } \\
\text { diákjai }\end{array}$ \\
\hline 2007. július 8 . & Pesávár (KP) & löfegyver & 4 & n. i. \\
\hline 2007. július 19 . & Hub (Beludzsisztán) & robbantás & 0 & n. i. \\
\hline 2012. február 28. & Pesávár (KP) & lőfegyver & 1 & $\begin{array}{l}\text { Tehrík-e } \\
\text { Talibán } \\
\text { Pakisztán } \\
\text { (TTP) }\end{array}$ \\
\hline 2012. július 23. & Karacsi (Szindh) & robbantás & 3 & n. i. \\
\hline 2013. május 21. & Karacsi (Szindh) & robbantás & 1 & n. i. \\
\hline 2013. június 22. & Gilgit-Baltisztán & lőfegyver & 3 & TTP \\
\hline 2014. május 19. & D. I. Khán (KP) & emberrablás & 1 & TTP \\
\hline 2016. május 30. & Karacsi (Szindh) & robbantás & 1 & $\begin{array}{l}\text { Szindhudés } \\
\text { Forradalmi } \\
\text { Párt (SFP) }\end{array}$ \\
\hline 2016. október 16. & $\begin{array}{l}\text { Ormára } \\
\text { (Beludzsisztán) }\end{array}$ & $\begin{array}{l}\text { IED improvised } \\
\text { explosive } \\
\text { device }\end{array}$ & 4 & $\begin{array}{l}\text { Beludzsisztán } \\
\text { Forradalmi } \\
\text { Hadsereg } \\
(\mathrm{BFoH})\end{array}$ \\
\hline 2016. december 14 . & Rohri (Szindh) & robbantás & 2 & n. i. \\
\hline 2017. május 24. & Kvetta (Beludzsisztán) & emberrablás & 2 & $\begin{array}{l}\text { IS (Iszlám } \\
\text { Állam) }\end{array}$ \\
\hline 2017. július 2 . & Ghótkí (Szindh) & lőfegyver & 1 & n. i. \\
\hline 2017. július 10 . & Karacsi (Szindh) & IED & 2 & $\begin{array}{l}\text { Szindhudés } \\
\text { Forradalmi } \\
\text { Hadsereg } \\
(\mathrm{SFH})\end{array}$ \\
\hline
\end{tabular}

\section{A DZSIHÁDISTA CSOPORTOK ÁLTAL ELKÖVETETT MERÉNYLETEK}

A fenti táblázat adatai alapján kitűnik, hogy 2016 előtt a kínai állampolgárok elleni támadások oroszlánrészét a pakisztáni tálib mozgalom (TTP) követte el. Az ugyanebben az időszakban történt további merényletek elkövetőiről nincs információ, ám a módszerük (robbantás, öngyilkos merénylet, egyéneket célzó 
támadások) tükrében egyes elemzők feltételezik, hogy ezek mögött is dzsihádista csoportok állnak (Syed, 2017). Ezekről azonban a támadás okait felvázoló deklaráció hiányában nehézkesen vonható le bármilyen megalapozott következtetés.

A támadások időbeli szórványos eloszlása azt sugallja, hogy a legtöbb eset izolált, vagyis nem bizonyított és nem is feltételezett közöttük közvetlen összefüggés. Egyetlen kivételt képez a 2007-es év, mikor néhány hónap leforgása alatt több merénylet is történt, és pakisztáni források szerint ezek közül két esemény összefüggésben állt egymással. 2007-ben Parvéz Musaraf pakisztáni elnök kemény fellépést kezdeményezett a hírhedt iszlámábádi Lál Maszdzsiddal szemben, a mecset imámja által hirdetett ideológiát követők radikális cselekményei miatt. Az egyik ilyen eset kilenc kínai állampolgár elrablása volt, melynek okaként a prostitúció gyanúját és a munkahelyükként szolgáló szalon muszlim értékrenddel összeegyeztethetetlennek tartott tevékenységét nevezték meg az elkövető Lál Maszdzsid madraszájának tanulói. Bár az elrablók szabadon engedték a túszokat, az eset nagy sajtóvisszhangot keltett mind Kínában, mind Pakisztánban, és ezt a támadást követte Musaraf Lál Maszdzsiddal szembeni kemény fellépése, részben kínai ösztönzésre (bár a kínai beavatkozásra nincs bizonyíték, a témával foglalkozó elemzők valószínűnek tartják). A tálibokkal szimpatizáló militáns csoportok további, föként Észak-Vazirisztán területén elkövetett terrortámadásokkal reagáltak a tisztogató akcióra. Ezek közül mindössze egy követelt kínai halálos áldozatokat: 2007 júniusában egy pesávári merényletben három kínai állampolgár vesztette életét, egy pedig súlyosan megsérült. Bár az elkövetőket nem azonosították, a pakisztáni hadsereg a Lál Maszdzsid elleni fellépéssel hozta összefüggésbe az esetet.

A támadások módszerét tekintve a lőfegyveres, illetve robbantásos merényletek a leggyakoribbak, azonban a TTP emberrablásokért is felelősséget vállalt. Hagyományosan a TTP áll a legtöbb emberrablás mögött Pakisztánban - ez a támadási módszer mindig is része volt a pakisztáni tálib mozgalom eszköztárának, bár a csoport jellemzően főként európaiakat és amerikaiakat céloz (a TTP vállalta a felelősséget például Piotr Stańczak lengyel mérnök elrablásáért és kivégzéséért 2008-ban és egy svájci pár elrablásáért 2011-ben). Ezekben az esetekben a csoport célja rendszerint váltságdíj szerzése, illetve saját militánsaik szabadon engedése, ám 2014-ben a kínai állampolgárok elrablásának esetében a TTP csupán harcosainak szabadon engedését követelte, de nem kért váltságdíjat. Ebben tehát a TTP eltért az általános gyakorlattól.

A pakisztáni dzsihádista csoportok által elkövetett, kifejezetten külföldi állampolgárokat célzó támadások mögött a fent említett anyagi megfontolások mellett ideológiai motivációk is meghúzódnak. Ezen csoportok az iszlám vallással összeegyeztethetetlen értékeket szimbolizáló „nyugati” jelenlét elleni tiltakozásként támadnak külföldi és nem muszlim célpontokat, ám a rendelkezésre álló adatok alapján úgy tünik, hogy a kínai állampolgárok ebből a szempontból nem számítanak kiemelt célpontnak. 2007 és 2017 között csupán a már említett iszlá- 
mábádi eset mögött állt deklarált erkölcsi-ideológiai megfontolás. Ezen kívül az elmúlt évtized során egyetlen olyan támadás történt, ami mögött egyértelmüen Kína-ellenes motiváció, vagyis a Hszincsiangban (Xinjiang) elő muszlimokkal való szolidaritás állt. Az egy kínai állampolgár halálát követelő, 2012-es pesávári lőfegyveres támadás után az elkövető TTP szóvivője, Mohammad Afrídi „hszincsiangi muszlim testvéreink meggyilkolásáért Kína ellen elkövetett bosszúként” aposztrofálta az esetet. Afrídi hozzátette továbbá, hogy a TTP a jövőben is kínai állampolgárok elleni támadásokat fog véghezvinni, amennyiben Kína a továbbiakban is támogatja Iszlámábád kemény fellépését a militáns dzsihádista mozgalmak ellen (URL1). Bár 2012 óta nem történt hasonló okokból elkövetett támadás, a TTP hszincsiangi muszlimokkal való szolidaritása és ennek ideológiai háttere kiemelt figyelmet igényel.

Itt érdemes külön kitérni a Kína-ellenes ideológiára, mint biztonsági problémára, illetve az ujgur szeparatizmus és a Kelet-Turkesztáni Iszlám Mozgalom (KTIM) pakisztáni jelenlétére. A kínai fennhatóság alatt álló Hszincsiang tartomány etnikai ujgur muszlim lakosságának szeparatista csoportjai évtizedek óta aktívan küzdenek a terület elszakadásáért. Az ujgur szeparatista ideológia legjelentősebb képviselöje a Kelet-Turkesztáni Iszlám Mozgalom nevű ernyőszervezet, melynek tagjai 2009-ben a kínai kormány Hszincsiang tartományra gyakorolt megszorító intézkedéseit és szigorú ujgurellenes fellépését követően többek között a pakisztáni-afganisztáni határvidék egyes törzsi területein, föként Észak-Vazirisztánban találtak menedékre, valamint ideológiai és fegyveres támogatásra. A KTIM 1997-es megalakulása óta rendelkezik pakisztáni kapcsolatokkal, vezetői pakisztáni madraszákban tanultak, és a szervezet kötődése az al-Káidához bizonyított tény (Reed-Raschke, 2010, 77.; Xu et al., 2014). 2005-ben a KTIM akkori amírja (vezetö), Abd al-Hakk Turkesztáni az al-Káida súrájának (tanács) tagja volt, pakisztáni források szerint Abdul Sakúr, a KTIM későbbi amirja pedig az al-Káida pakisztáni törzsi területeken fenntartott kiképzőtáborainak egyikét vezette (Potter, 2013, 75.). Az al-Káidával való kapcsolata és tagjainak a szervezetben játszott szerepe révén a KTIM tehát előkelő helyet szerzett a globális dzsihádista militáns csoportok között.

A KTIM rendszerint hangot ad Kína-ellenes ideológiájának, és kínai célpontok elleni támadásokra buzdít. Abd al-Hakk Turkesztáni egy 2009-ben kiadott nyilatkozatában az ujgurokkal való szolidaritásra és kínaiak ellen elkövetett támadásra szólított fel: „,[A] kínaiak célponttá kell hogy váljanak mind az országban, mind pedig azon kívül. A nagykövetségeiket, konzulátusaikat, bázisaikat és gyüléseiket támadni kell, az embereiket és családjaikat le kell gyilkolni, hogy megválthassuk a Kelet-Turkesztánban fogvatartott testvéreinket. Az összes ilyen cselekedet segíti kelet-turkesztáni testvéreinket.” (idézi Fishman, 2011, 52.)

Turkesztáni üzenete meghallgatásra talált bizonyos radikális militáns csoportok - például az al-Káida - vezetőinél, akik szintén az ujgurokkal való szolidari- 
tásra buzdítottak, bár nem uszítottak közvetlenül Kína és kínai célpontok elleni támadásra. (Ez alól kivételt képez Abú Jahja al-Libi, az al-Káidában 2012-es haláláig központi szerepet betöltő líbiai származású vezetö, aki az ujgur népcsoportot Kína elleni fegyveres fellépésre buzdította.)

A KTIM nemzetközi jelenléte, kapcsolati hálója, külföldön elkövetett merényletei, valamint ideológiai befolyása tehát különösen aggasztó Kína számára. Egyes elemzők a globális dzsihádista csoportok Pakisztánon kívüli tevékenységét és ideológiai változásait is figyelembe véve arra mutatnak rá, hogy ezekben a csoportokban a Kína-ellenes ideológia átvétele csupán csak idő kérdése (Fishman, 2011). Ezt az előrejelzést Pakisztánban mind ez idáig egyetlen támadás - a már említett 2012-es pesávári merénylet - erősítette meg, bár megjegyzendő, hogy a KTIM pakisztáni ideológiai befolyásáról rendkívül kevés információ áll rendelkezésre. Összességében tehát a Pakisztán területén kínai állampolgárok ellen elkövetett támadások módja és az ezek nagy részét követő csend (vagyis a támadást magára vállaló csoport hiánya) arra engednek következtetni, hogy a Kína-ellenes ideológia Pakisztánban még nem vert gyökeret a helyi dzsihádista csoportok gondolkozásában. Ehhez azonban kétségkívül biztosíthatja a táptalajt a KTIM kiterjedt kapcsolatrendszere a térségben jelen lévő dzsihádista csoportokkal, továbbá az ideológiai fenyegetés komolyságát bizonyítja Iszlámábád radikális KTIM-ellenes kiállása is. Mamnún Huszein volt pakisztáni elnök rendszerint Kína és Pakisztán közös ellenségeként utalt az KTIM-re, és Pakisztán harca a KTIM ellen nem ragad meg retorikai szinten: a KTIM két korábbi amírját a pakisztáni haderő likvidálta (Rehman, 2014, 2.), továbbá a pakisztáni hadsereg Zarb-e Azb tisztogató hadmúveletének (2014-2017) egyik kiemelt célja volt az KTIM Észak-Vazirisztánból való kiüzése. A hadsereg közleményei szerint az offenzíva során sikeresen megsemmisítették az ETIM pakisztáni jelenlétét, melyröl a kínai fél is elismerően nyilatkozott (URL2). A dzsihádista csoportok által elkövetett kínai személyeket célzó támadások száma 2015 után kétségkívül csökkent - az elmúlt két év során csupán egyetlen merénylet történt, 2017 júniusában az IS helyi szervezete elrabolt, majd kivégzett két kínai nyelvtanárt Kvettában. A tendencia tehát javul, ám a pakisztáni hadsereg hadmüvelete és a merényletek számának csökkenése között egyelöre nincs egyértelmüen bizonyított korreláció - ahogyan a fenti táblázat adatai rámutatnak, dzsihádista csoportok már 2014 során sem követtek el támadásokat.

\section{SZEPARATISTA CSOPORTOK MOTIVÁCIÓ ÉS TÁMADÁSAI}

A táblázat 2016 utáni adatai új tendencia felé mutatnak: ebben az időszakban a legtöbb, kínai állampolgárok elleni merényletet szindhi és beludzs szeparatista csoportok követték el. Ezek a támadások szoros összefüggésben állnak a bilaterális megállapodáson alapuló Kína-Pakisztán Gazdasági Folyosó (KPGF) nevü 
fejlesztési megaprojekt 2015-ben megkezdett kivitelezési munkálataival, amit az alapvetően államellenes beludzs és szindhi szeparatista csoportok hevesen elleneznek. Ennek oka, hogy a szeparatista mozgalmak a pandzsábi befolyás kiterjesztéseként, kulturális imperializmusként, valamint gazdasági kizsákmányolásként értékelik az állami projekteket, így a KPGF-et is. Számos hasonlóság figyelhető meg a beludzs és a szindhi nacionalista, illetve szeparatista csoportok Kínával és a KPGF-fel szembeni fellépése és a kínai jelenlét elleni érvei között: a Kína-ellenesség mindkét tartomány említett mozgalmainál abból fakad, hogy a szeparatista csoportok számára a KPGF a pakisztáni kormány által gyakorolt elnyomást és a „szindhi és beludzs nemzetek kulturális, gazdasági és földrajzi jelenlétére kirótt halálos ítéletet" szimbolizálja (URL3). A kínai állampolgárok ellen elkövetett támadások mögötti motiváció a beludzs és szindhi szeparatista csoportok esetében elsődlegesen tehát nem a Kína-ellenes ideológia, hanem a kínai gazdasági befolyás által jelentett egzisztenciális fenyegetés, illetve fontos még az Iszlámábádnak nyújtott kínai támogatás folyósításának megakadályozása.

A két tartomány közül a beludzs biztonsági helyzet jelent nagyobb kihívást a projektekre nézve. Beludzsisztán az eredeti tervek szerint föszerepet kapott volna a KPGF kivitelezésében, Gvádar stratégiai jelentőségét felismerve a pakisztáni vezetés Beludzsisztánt nevezte meg a KPGF jövőbeni fő nyerteseként, valamint a Beludzsisztánon keresztülhaladó úgynevezett nyugati folyosó megépítése kapott prioritást a kivitelezési tervekben. Gyakorlatban azonban a 2015-ös tervektől radikálisan eltérő módon zajlanak a kivitelezési munkálatok: a megkezdett projektek túlnyomó többsége Pandzsáb tartományban koncentrálódik. Beludzsisztán alapvető biztonsági instabilitása egyrészt a már említett dzsihádista csoportok jelenlétéből, másrészt pedig a tartomány marginalizált gazdasági, politikai és szociális helyzetéből és az erre válaszul jelentkező beludzs fegyveres ellenállásból fakad. A beludzs szeparatista csoportok radikális eszközökkel tiltakoznak mind az állami tevékenységek, mind pedig a kínai jelenlét ellen. A támadások kiemelt célpontjai hagyományosan az állam és a hadsereg infrastruktúrája és személyi állománya, valamint a külföldi befektetések. Ugyanezen szeparatista csoportok állnak a kínai infrastruktúra és személyek elleni merényletek mögött: a 2016-os kínai állampolgárokat célzó támadásért a Beludzs Forradalmi Hadsereg militánsai vállaltak felelősséget, Szindh tartományban pedig a Szindh Forradalmi Hadsereg (SFH) és a Szindhudés Forradalmi Párt (SFP) tagjai követtek el egy-egy merényletet. Utóbbit bizonyította például a 2016-ban Karacsiban egy kínai mérnök ellen elkövetett támadás után a helyszínen talált röpirat. Ebben az SFP magára vállalta a merényletet, és kifejtette Kínáról alkotott nézeteit - a párt ebben Kínát Pakisztán szövetségeseként definiálta, mely „koalíció aktívan kisemmizi és rabszolgasorsba taszítja Szindhet”. Ebből az okból kifolyólag a párt a röpiratban Kína tudomására hozta, hogy 
„minden Szindh-ellenes projektet ellenez, a Kína-Pakisztán Gazdasági Folyosót is beleértve" (Ali, 2016).

A szeparatista pártok által elkövetett kínai személyeket célzó támadások száma kifejezetten alacsony volt a fent említett biztonsági helyzetet javító intézkedések előtt is. Fontos azonban kiemelni, hogy a kínai állampolgárokat célzó támadás mint terminus nem összetévesztendő a KPGF ellen elkövetett merényletekkel, hiszen utóbbiak nem csupán kínai állampolgárok, hanem a projekt számára kiemelten fontos infrastruktúra és a KPGF-en dolgozó személyek és fejlesztési területek ellen is intéznek támadásokat. Ezen merényletek száma Beludzsisztán és Szindh tartományokban jóval magasabb a kínai személyek ellen elkövetett támadásokénál. A szeparatista pártok tevékenysége által jelentett biztonsági kihívást felismerve a pakisztáni kormány jelentősen emelte a KPGF-en dolgozó kínai állampolgárok biztonságát garantáló fegyveres őrök számát. Ez a biztonsági intézkedés azonban nem vonatkozik azokra a kínai állampolgárságú személyekre, akik nem KPGF-projekteken dolgoznak, így a kormány eddigi intézkedései nem jelentenek megoldást az átfogó problémára.

\section{KONKLÚZIÓ}

A kínai állampolgárok ellen elkövetett merényletek száma az összes terrorcselekmény számához képest igen alacsony: a Global Terrorism Database adatai szerint 2007 és 2016 között összesen 11332 terrorcselekmény történt Pakisztánban, ezek közül mindössze tizennégy irányult kínai állampolgárok ellen (URL4; jelen tanulmányban kizárólag nyilvános adatokkal dolgozom, így nem zárható ki annak a lehetősége, hogy a kínai állampolgárok ellen elkövetett merényletek valós száma magasabb, mint ami a sajtó által közölt adatokból leszürhető). Ezek között csupán egy ideológiai okból elkövetett támadás volt, ám a Kína-ellenes fordulat bekövetkeztének lehetősége a nemzetközi hálózattal rendelkező dzsihádista csoportok gondolkodásában láthatóan nyugtalanítja mindkét érintett felet. Pakisztán legföbb stratégiai partnere és befektetője Kína, így az ország nem engedheti meg a kínai állampolgárok elleni támadások számának növekedését. Emiatt a dzsihádista csoportok - és kiemelten a KTIM - féken tartására történtek komoly kísérletek, mint például a fent említett Zarb-e Azb hadmüvelet.

A KPGF-projekt 2015-ös kezdete után új biztonsági kihívás jelent meg a beludzs és szindhi szeparatista csoportok Kína- és KPGF-ellenes megmozdulásaival. A szeparatista csoportok által jelentett biztonsági fenyegetés csökkentésére szintén történtek és történnek kísérletek, mint például a biztonsági személyzet számának növelése, mely a KPGF-en dolgozó személyek elleni támadások kivitelezését kétségkívül nehezíti. A Pakisztán területén tartózkodó, nem KPGF-en 
dolgozó kínai személyeknek azonban nem jár alanyi jogon fegyveres kíséret, így ezen személyek védelme továbbra sem megoldott. Továbbá, a biztonsági személyzet számának növelése csupán a „tünetet” kezeli, a fennálló problémát kétségkívül nem tudja megoldani. Így az államellenes ideológia erösödése és az ezzel szoros összefüggésben álló ellenérzések a kínai jelenléttel kapcsolatban valószínűsíthetően további támadásokhoz fognak vezetni Beludzsisztánban és Szindhben.

Kína növekvő pakisztáni jelenlétével párhuzamosan óhatatlanul növekszik tehát a biztonsági kockázat is, Kína pedig láthatóan tisztában van az állampolgárait fenyegető veszélyekkel. Ezt mutatja a nagykövetség által kiadott figyelmeztetés 2017 decemberében, ami a növekvő Kína-ellenes terrorfenyegetéstől tartva fokozott óvatosságra szólította fel a Pakisztánban élő kínai állampolgárokat (URL5). Emellett Peking folyamatos nyomást gyakorol Pakisztánra a biztonsági helyzet javításának érdekében, amit a pakisztáni kormány és hadsereg a kapacitásaihoz képest kétségkívül komolyan vesz. Az azonban továbbra is kétséges, hogy a pakisztáni vezetés képes-e kezelni a problémák gyökerét, vagyis egyrészt visszaszorítani a dzsihádista szervezeteket, és stabilizálni az ezeknek menedéket nyújtó törzsi területeket, másrészt pedig megoldást találni Beludzsisztán (és Szindh) jobb integrálására és gazdasági helyzetének javítására, ezáltal pedig csökkenteni a szeparatista csoportok mozgásterét.

\section{IRODALOM}

Ali, I. (2016): Chinese Citizen Targeted in Karachi Blast. Dawn, http://www.dawn.com/ news/1261600

Fishman, B. (2011): Al-Qaeda and the Rise of China: Jihadi Geopolitics in a Post-Hegemonic World. The Washington Quarterly, 34, 3, 47-62. https://csis-prod.s3.amazonaws.com/s3fs-public/legacy_files/files/publication/twq11summerfishman.pdf

Potter, P. B. K. (2013): Terrorism in China. Growing Threats with Global Implications. Strategic Studies Quarterly, 7, 4, 70-92. https://www.airuniversity.af.edu/Portals/10/SSQ/documents/ Volume-07_Issue-4/2013winter-Potter.pdf

Reed, J. T. - Raschke, D. (2010): The ETIM: China's Islamic Militants and the Global Terrorist Threat. Santa Barbara: Praeger

Rehman, Z. U. (2014): ETIM's Presence in Pakistan and China's Growing Pressure. Norwegian Peacebuilding Resource Centre, https://www.files.ethz.ch/isn/183175/381280b226170116bb6f07dc969cb17d.pdf

Syed, J. (2017): Terrorising the Belt and Road: A Critical Analysis of Security Threats to Chinese Nationals and Businesses in Pakistan. (LUMS Working Paper: CPMI/2017/11/2). Lahore: Suleman Dawood School of Business, Lahore University of Management Sciences, https://cpmi. lums.edu.pk/sites/default/files/media-browser/cpec_security_paper_js_18nov17.pdf

Xu, B. - Fletcher, H. - Bajoria, J. (2014): The East Turkestan Islamic Movement (ETIM). Council on Foreign Relations, https://www.cfr.org/backgrounder/east-turkestan-islamic-movement-etim 
URL1: China Warns of Imminent Attacks by “Terrorists" in Pakistan. (2017), https://www.reuters. com/article/us-china-silkroad-pakistan/china-warns-of-imminent-attacks-by-terrorists-in-pakistan-idUSKBN1E216N

URL2: Press Release No PR-375/2015-ISPR. (2015), https://ispr.gov.pk/press-release-detail. php?id=3121

URL3: Sayed's 113th Birth Anniversary Observed: JSMM Announces Strike against CPEC. (2017), http://industribune.net/news/sayeds-113th-birth-anniversary-observed-jsmm-announces-strike-cpec/2787

URL4: Global Terrorism Database. (2018), https://bit.ly/2N0eC0F

URL5: Chinese Workers Feared Dead in Pakistan Bombing. (2007), http://www.chinadaily.com. cn/china/2007-07/19/content_5439706.htm 